\title{
Biomarker records, organic carbon accumulation, and river discharge in the Holocene southern Kara Sea (Arctic Ocean)
}

\author{
K. Fahl • R. Stein
}

Received: 17 July 2006 / Accepted: 22 November 2006 / Published online: 4 January 2007

(C) Springer-Verlag 2007

\begin{abstract}
Within the Russian-German research project on "Siberian River Run-off (SIRRO)" dealing with freshwater discharge and its influence on biological, geochemical, and geological processes in the Kara Sea, sedimentological and organic-geochemical investigations were carried out on two well-dated sediment cores from the Yenisei Estuary area. The main goal of this study was to quantify terrigenous organic carbon accumulation based on biomarker and bulk accumulation rate data, and its relationship to Yenisei river discharge and climate change through Holocene times. The biomarker data in both cores clearly indicate the predominance of terrigenous organic matter, reaching 70-100 and $50-80 \%$ of total organic carbon within and directly north of the estuary, respectively. During the last ca. 9 cal ka B.P. represented in the studied sediment section, siliciclastic sediment and (terrigenous) organic carbon input was strongly influenced by postglacial sea-level rise and climate-related changes in river discharge. The mid-Holocene Climatic Optimum is documented by maximum river discharge between 8.2 and $7.3 \mathrm{cal}$ ka B.P. During the last 2,000 years, river discharge probably decreased, and accumulation of both terrigenous and marine organic carbon increased due to enhanced coagulation of finegrained material.
\end{abstract}

\section{Introduction}

The Arctic Ocean, surrounded by the world's largest shelf seas, is characterized by its seasonal to permanent sea-ice cover and its huge river discharge. Although the Arctic

K. Fahl $(\bowtie) \cdot$ R. Stein

Alfred Wegener Institute for Polar and Marine Research,

27568 Bremerhaven, Germany

e-mail: Kirsten.Fahl@awi.de
Ocean represents only about $2.3 \%$ of the world ocean area, the Arctic river discharge is equivalent to $10 \%$ of the global runoff (Aagaard and Carmack 1989). Within this context, the Kara Sea is of special importance, receiving about $50 \%$ $\left(1,480 \mathrm{~km}^{3}\right.$ year $\left.^{-1}\right)$ of the total river runoff discharged to the Eurasian Arctic as a whole (Gordeev et al. 1996; Holmes et al. 2002; Peterson et al. 2002; Rachold et al. 2004). Most of this discharge is from the major rivers $\mathrm{Ob}$ and Yenisei, contributing 404 and $620 \mathrm{~km}^{3}$ year ${ }^{-1}$, respectively (Fig. 1). Furthermore, large amounts of dissolved and particulate (organic and inorganic) material are transported by these major Arctic rivers (Rachold et al. 2004 and references therein). The modern discharge of total suspended matter by the $\mathrm{Ob}$ and Yenisei rivers is $15.5 \times 10^{6}$ and $4.7 \times 10^{6} \mathrm{t} \mathrm{year}^{-1}$, respectively. The particulate organic carbon supply by these two rivers is estimated to reach about $0.36 \times 10^{6}$ and $0.17 \times 10^{6} \mathrm{t} \mathrm{year}^{-1}$, respectively. A large part of the riverine suspended matter is trapped in the estuaries, however, the so-called marginal filter, where river current velocities decrease, and freshwater mixes with saltwater (salinities of about 2-10) and rapid accumulation of fine-grained suspension occurs due to flocculation/ aggregation processes (Lisitzin 1995).

A major source of the suspended matter of the Yenisei River are the widespread Triassic plateau basalts and tuff deposits of the Putoran Massif (Fig. 1; Duzhikov and Strunin 1992). About $70 \%$ of the modern annual Yenisei discharge is contributed by the main tributaries Nizhnyaya Tunguska River and Podkamennaya Tunguska River, draining this area (Meade et al. 2000). Because basalts and their weathering products are generally characterized by high magnetic susceptibility values (Thompson and Oldfield 1986), the Yenisei input can be identified in the sedimentary records from the southern Kara Sea by its high magnetic susceptibility (Dittmers et al. 2003; Stein et al. 2003a, 2004). 
Fig. 1 Satellite photograph of the southern Kara Sea (http://www.visibleearth.nasa. gov), with location of cores BP99-04/07 and BP00-07/07. Values of river discharge, total suspended matter (TSM), and particulate organic carbon (POC) supply are from Rachold et al. (2004)

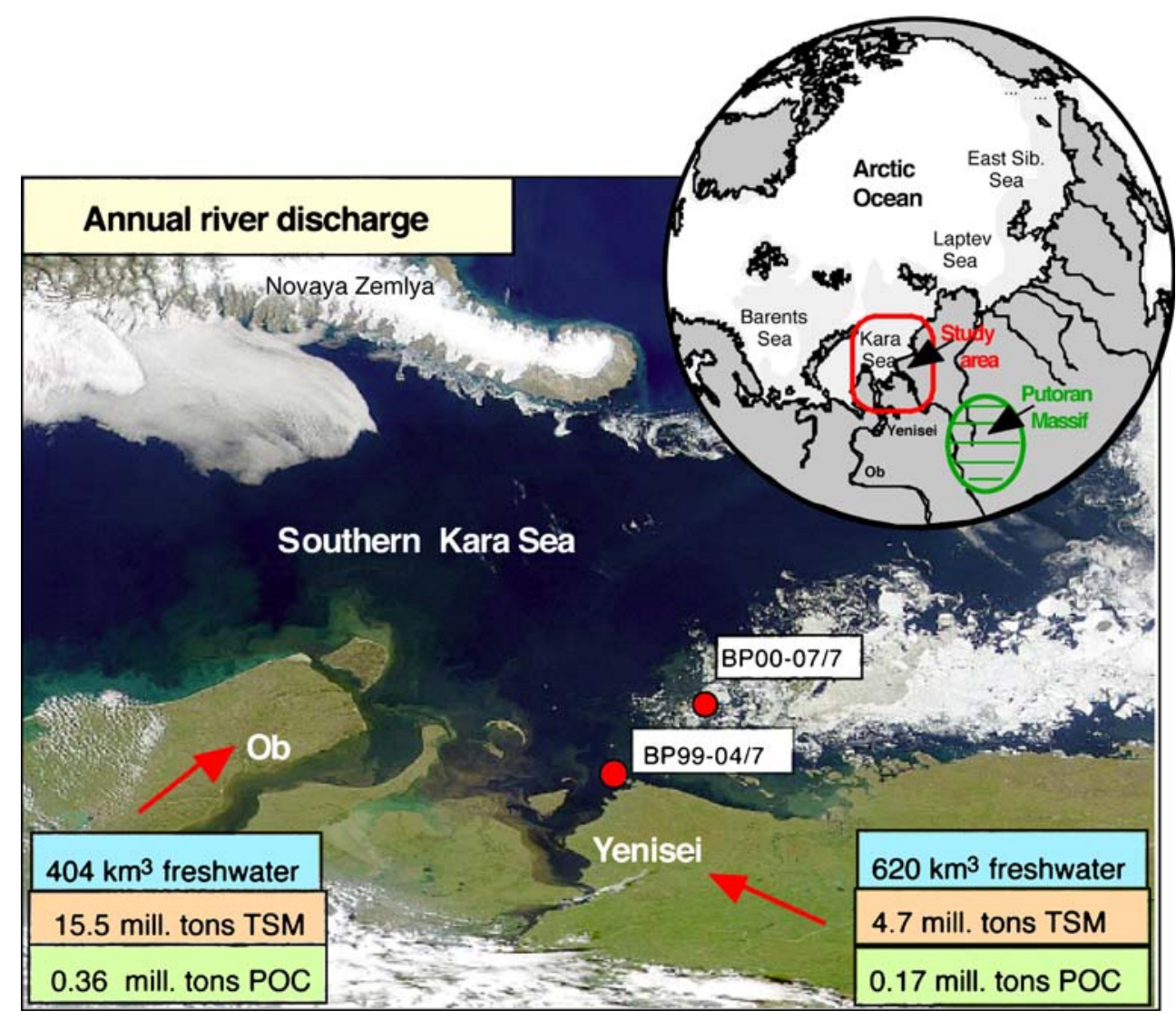

In view of the importance of river discharge in the region, a Russian-German research project on "Siberian River Run-off (SIRRO)" was initiated to study in detail the freshwater discharge, its influence on biological, geochemical and geological processes in the Kara Sea, and its variability in space and time (Stein et al. 2003b and references therein). Here, we present new results of biomarker studies performed on two well-dated sediment cores from the southern Kara Sea within and directly north of the Yenisei Estuary (Fig. 1). The main goal of this paper is to quantify terrigenous organic carbon accumulation based on biomarker data and its relationship to river discharge and climate change through Holocene times.

\section{Proxies for organic carbon sources}

In order to determine the terrigenous and marine proportions of organic matter, organic-geochemical bulk parameters ( $\mathrm{C} / \mathrm{N}$ ratios, $\delta^{13} C_{\text {org }}$ values, Rock-Eval parameters), maceral composition and specific biomarker distributions have proved useful (e.g. Meyers 1997; Fahl and Stein 1999). In this study, we used the distribution of long-chain $n$-alkanes (e.g. Nichols et al. 1984; Prahl and Muehlhausen 1989; Yunker et al. 1995) as well as the specific sterols 24ethylcholest-5-en-3 $\beta$-ol ( $\beta$-sitosterol) and 24-methylcho- lest-5-en-3 $\beta$-ol (campesterol; e.g. Huang and Meinschein 1976; Volkman 1986) and long-chain fatty acids with carbon-chain length $>$ C24 (e.g. Parrish et al. 2000) as biomarker proxies for the input of land-derived vascular plant material. As indicators for marine-derived organic matter, the sterol $4 \alpha$-23,24-trimethyl-5 $\alpha$-cholest-22E-en$3 \beta$-ol (dinosterol; e.g. Huang and Meinschein 1976; de Leeuw et al. 1983; Volkman 1986; Volkman et al. 1993) and the short-chain diatom-specific fatty acids $16: 1(n-7)+$ 16:1(n-5)+20:5(n-3) (Kates and Volcani 1966; Ackman et al. 1968; Kattner et al. 1983; Nichols et al. 1984; Fahl and Kattner 1993; Fahl and Stein 1997) were determined. For organic-geochemical bulk parameters and maceral composition of Kara Sea sediments, we refer to Stein and Fahl (2004) and references therein.

One approach to quantify the proportion of terrigenous organic matter is based on long-chain $n$-alkanes. Prahl and Carpenter (1984) examined long-chain $n$-alkane distributions in surface sediments from the Pacific coast off Washington State. They found that, when expressed in $\mu \mathrm{g}$ $\mathrm{g}_{\mathrm{oc}}^{-1}$, the levels of sums of odd $n$-alkanes $\mathrm{C}_{25}$ to $\mathrm{C}_{31}$ were fairly constant, despite large variability in $\mathrm{OC}$ contents. Based on this observation, they developed a simple binary model assuming that (1) long-chain $n$-alkanes and terrestrial organic carbon (ALKOC) are exported at the mouth of the Columbia River to the Washington coast in a fixed ratio and 
(2) a change in the ALKOC ratio determined in coastal surface sediments is caused by "dilution" of terrestrial organic carbon with marine organic carbon which does not contain long-chain $n$-alkanes (Prahl and Carpenter 1984; Prahl and Muehlhausen 1989; Prahl et al. 1994). Accordingly, the percentage of terrigenous organic carbon (TerrOC) at each station can be calculated from the content of long-chain $n$-alkanes in $\mu \mathrm{g} \mathrm{g}_{\mathrm{oc}}^{-1}$ normalized to the ALKOC ratio:

$$
\operatorname{TerrOC}(\%)=\frac{\left[\mathrm{C}_{25-31}\left(\mu \mathrm{g} \mathrm{g}_{\text {sed }}^{-1}\right) / \mathrm{OC}\left(\mathrm{g} \mathrm{g}_{\text {sed }}^{-1}\right)\right]_{\text {sample }}}{\operatorname{ALKOC}} \times 100
$$

This approach has been successfully applied for Kara Sea surface sediments (Fig. 2). Fernandes and Sicre (2000) found that the $\mathrm{Ob}$ and Yenisei rivers also supply long-chain $n$-alkanes into the Kara Sea as a relatively constant ratio of organic carbon content (ALKOC ratio=451), as indicated by the following equation:

$$
\operatorname{sum} \mathrm{C}_{25-31}=451 \times \mathrm{OC}+0.117 \quad\left(\mathrm{r}^{2}=0.95\right)
$$

where the sum of odd $n$-alkanes $C_{25}$ to $C_{31}$ is given in $\mu \mathrm{g} \mathrm{g}_{\text {sed }}^{-1}$ and $\mathrm{OC}$ in $\mathrm{g} \mathrm{g}_{\text {sed }}^{-1}$. The correlation between the long-chain $n$ alkanes and OC content of surface sediments from the rivers and estuaries indicates that, in the absence of long-chain $n$ alkanes, OC contents reach values of about zero, which implies that the organic matter is almost entirely terrigenous

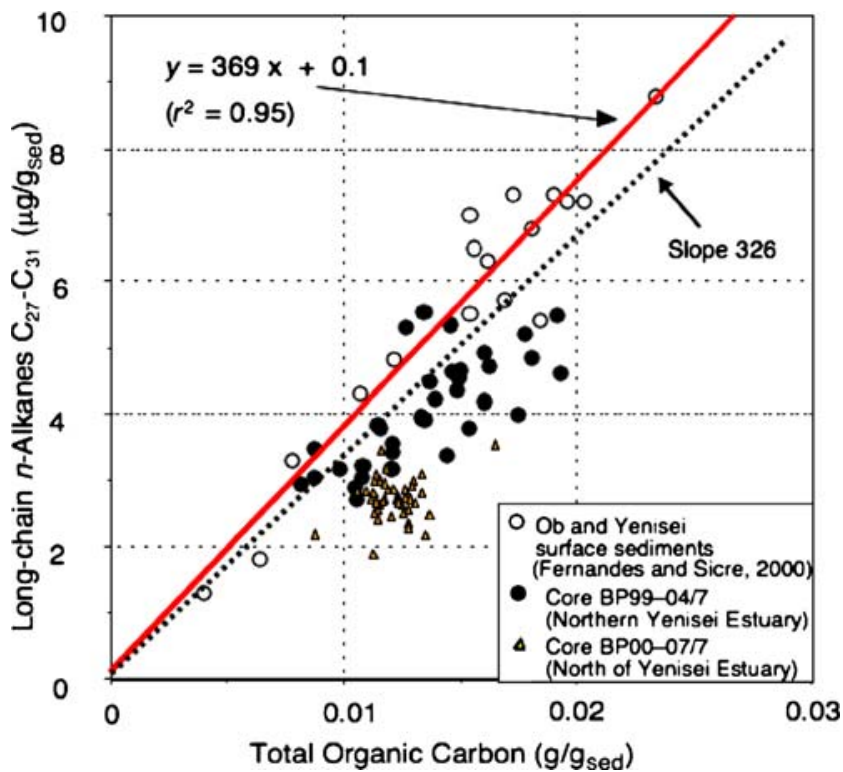

Fig. 2 Total organic carbon (TOC) versus long-chain $n$-alkanes correlation in surface sediments from the $\mathrm{Ob}$ and Yenisei estuaries (Fernandes and Sicre 2000; Stein and Fahl 2004). In addition, data from core BP99-04/07 and core BP00-07/7 are included. For further explanation, see text
(Fig. 2). Using the equation for TerrOC and an ALKOC ratio of 451, TerrOC can then be calculated.

To compare the Fernandes and Sicre (2000) data with our surface sediment data from the Kara and Laptev seas as well as the St. Anna Trough where we used the sum of odd $n$-alkanes $\mathrm{C}_{27}$ to $\mathrm{C}_{31}$ as a proxy for terrigenous input (Fahl et al. 2001, 2003; Stein and Fahl 2004), we re-plotted the Fernandes and Sicre dataset, using only the sum of $\mathrm{C}_{27}$ to $\mathrm{C}_{31}$. Accordingly,

$\mathrm{C}_{27+29+31}=369 \times \mathrm{OC}+0.104 \quad\left(\mathrm{r}^{2}=0.95\right)$

corresponding to an ALKOC ratio of 369 (Fig. 2). The correlation coefficient and calculated proportions of terrigenous organic carbon remain the same. Including more surface sediment data from the Yenisei Estuary, Stein and Fahl (2004) reported a slightly modified correlation with an ALKOC ratio of 326 (Fig. 2), which has been used in Eq. 1 to calculate the proportion of terrigenous organic matter in the sediments of cores BP99-04/7 and BP00-07/7.

\section{Materials and methods}

Within the framework of the joint Russian-German project on "Siberian River Run-off (SIRRO)," five multidisciplinary scientific expeditions aboard the RV Akademik Boris Petrov were carried out between 1999 and 2003, and several long sediment cores were obtained in the $\mathrm{Ob}$ and Yenisei estuaries and adjacent inner Kara Sea (Stein et al. 2003a,b). Core BP99-04/7 (73²4.89'N, 7940.48'E; water depth $32 \mathrm{~m}$ ), situated in the northern area of the Yenisei Estuary, and core BP00-07/7 (74²39.46'N, 81 ${ }^{\circ} 08.47^{\prime} \mathrm{E}$; water depth $38 \mathrm{~m}$ ), situated directly north of the Yenisei Estuary, were selected as key datasets to study the variability of Holocene Siberian climate and discharge of the Yenisei River (Fig. 1; Stein and Stepanets 2000, 2001). Both cores consist mainly of bioturbated dark olive silty clay to clayey silt (lithological unit I; Fig. 3). In core BP9904/7, unit I can be subdivided into a bioturbated upper subunit Ia and a laminated lower subunit Ib. The main sediment components are clay minerals and quartz; additionally, feldspar, rock fragments, heavy minerals, and plant debris as well as benthic foraminifers may occur in minor but significant amounts (Stein and Stepanets 2001). Thus, the sediments predominantly represent siliciclastic sediments, and the calculated bulk accumulation rates can be interpreted as a signal for the input and accumulation of terrigenous (siliciclastic) matter (see Discussion).

\section{Chronology}

The chronology of the sedimentary record of both cores, representing the last ca. 9 cal ka B.P., is based on 19 


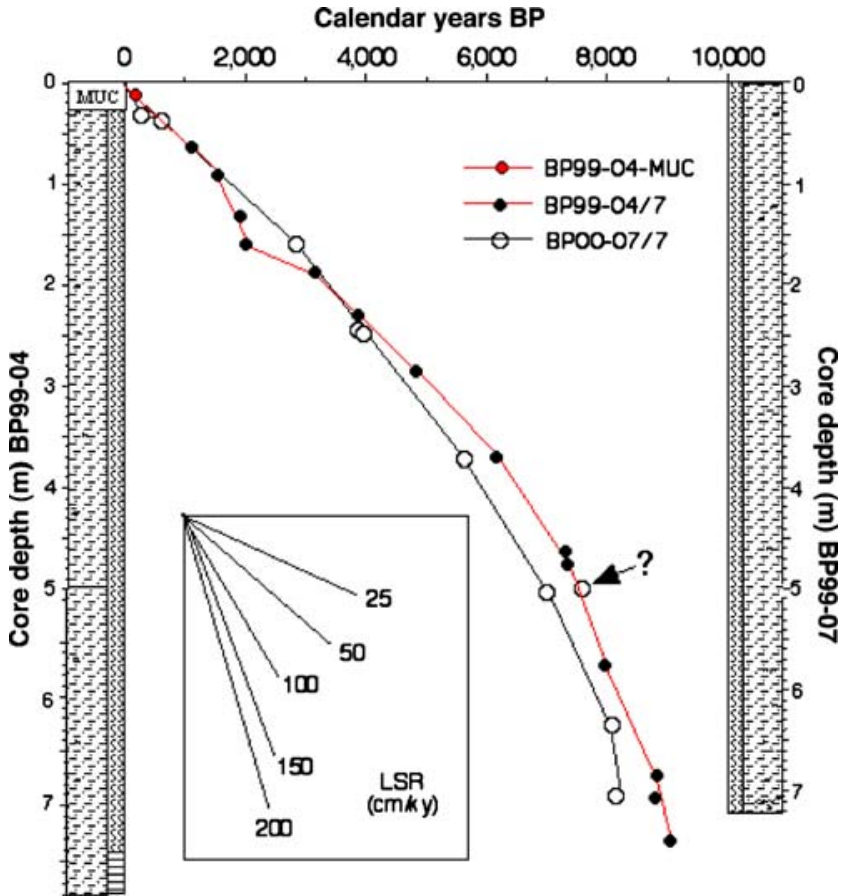

Fig. 3 Age/depth diagram, mean sedimentation rates, and lithologies of cores BP99-04/07 and BP00-07/07. For data base, see Table 1

AMS ${ }^{14} \mathrm{C}$ datings obtained on marine bivalves (Table 1). For core BP99-04/7, the uppermost ca. $30 \mathrm{~cm}$ representing the last ca. 750 cal years B.P. is unfortunately missing due to overpenetration of the gravity corer. In order to fill this gap in the record, multicorer core BP99-04/4, taken from the same location as core BP99-04/7 and representing a $25-\mathrm{cm}-$ thick undisturbed section of near-surface sediments, was "set" on top of the record of core BP99-04/7 (Fig. 3).

Based on this chronological framework, age/depth diagrams were produced (Fig. 3), and linear sedimentation rates (LSR) were calculated. LSR are very high, ranging between 28 and about $233 \mathrm{~cm} \mathrm{1,000} \mathrm{years}{ }^{-1}$ for core BP99-

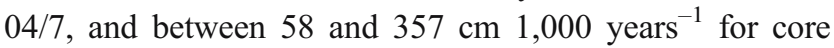
BP00-07/7. At both sites, the maximum LSR were calculated for the early Holocene time interval. Bulk as well as TOC accumulation rates used in this study partly differ from those published in Stein et al. (2003a, 2004), because here we include new $\mathrm{AMS}^{14} \mathrm{C}$ datings (Table 1).

Analytical methods

Total organic carbon (TOC) was measured by means of a LECO-CNS Analyser. The precision of this method is $0.05 \%$ for carbon. $\mathrm{C} / \mathrm{N}$ ratios were calculated as total organic carbon/total nitrogen ratios based on weight percentages.

For lipid analyses, the samples were extracted first with methanol, in a second step with dichloromethane:methanol (1/1 by vol.), and finally with dichloromethane. The total extract was transesterified using $3 \mathrm{~N}$ methanolic $\mathrm{HCl}\left(50^{\circ} \mathrm{C}\right.$ for $12 \mathrm{~h}$ ), a method modified according to Christie (1990) and Conte et al. (1992), and separated in fractions by column chromatography using $5 \mathrm{ml}$ hexane for the $n$ alkanes, $4 \mathrm{ml}$ dichloromethane for the fatty acids, and $5 \mathrm{ml}$ ethylacetate:hexane (20:80, by vol.) for the sterols as eluents. The sterols were silylated with $500 \mu$ l BSTFA (bis-trimethylsilyl-trifluoroacetamide; $60^{\circ} \mathrm{C}$ for $2 \mathrm{~h}$ ).

All components were analysed with a Hewlett Packard gas chromatograph (HP 6890, column $30 \mathrm{~m} \times 0.25 \mathrm{~mm}$; film thickness $0.25 \mu \mathrm{m}$; liquid phase: DB-5MS) using a temperature program as follows: $60^{\circ} \mathrm{C}(2 \mathrm{~min}), 150^{\circ} \mathrm{C}$ (rate: $15^{\circ} \mathrm{C} \min ^{-1}$ ), $320^{\circ} \mathrm{C}$ (rate: $3^{\circ} \mathrm{C} \min ^{-1} ; 20 \mathrm{~min}$ isothermal). The injection volume was $1 \mu \mathrm{l}$, using a cold injection system and the following temperature program: $60^{\circ} \mathrm{C}(0.1 \mathrm{~min}), 320^{\circ} \mathrm{C}$ (rate: $12^{\circ} \mathrm{C} \mathrm{s}^{-1}, 60 \mathrm{~s}$ ). Helium was used as carrier gas $\left(1.5 \mathrm{ml} \mathrm{min}^{-1}\right)$.

The identification of the components was supported by GC/MS, using a gas chromatograph (HP 5890, column $30 \mathrm{~m} \times 0.25 \mathrm{~mm}$; film thickness $0.25 \mu \mathrm{m}$; liquid phase: DB$5 \mathrm{MS}$ ) and a mass spectrometer (MSD, HP 5972, $70 \mathrm{eV}$ electron-impact-ionisation, scan $50-650 \mathrm{~m} / \mathrm{z}, 1 \mathrm{scan} \mathrm{s}^{-1}$, ion source temperature $175^{\circ} \mathrm{C}$ ). GC analysis was performed with the following temperature program: $60^{\circ} \mathrm{C}(2 \mathrm{~min})$, $150^{\circ} \mathrm{C}$ (rate: $15^{\circ} \mathrm{C} \min ^{-1}$ ), $320^{\circ} \mathrm{C}$ (rate: $3^{\circ} \mathrm{C} \mathrm{min}^{-1} ; 20 \mathrm{~min}$ isothermal). The injection volume was $1 \mu$ (splitless). Helium was used as carrier gas $\left(1.2 \mathrm{ml} \mathrm{min}^{-1}\right.$ at $\left.60^{\circ} \mathrm{C}\right)$.

The identification of the $n$-alkanes and fatty acids was carried out on the basis of GC retention time, and that of the sterols on the basis of GC retention time and MS fragmentation pattern. For quantification, internal standards (squalane, 19:0 fatty acid methyl ester and cholest-5-en-3 $\beta$ ol-2,2,3,4,4,6-d $\mathrm{d}_{6}$ ) were added before each analytical step.

The carbon preference index (CPI), i.e. the relation of odd-to-even chain lengths of $n$-alkanes between $\mathrm{C}_{21}$ and $\mathrm{C}_{32}$ (Bray and Evans 1961), is commonly used as a measure for the maturity of terrigenous organic matter. Fresh terrigenous organic material has a CPI-index of 3-10 (Brassell et al. 1978; Hollerbach 1985) whereas fossil material varies around 1, depending on the degree of diagenesis.

The data on total organic carbon content and biomarkers ( $n$-alkanes, fatty acids, and sterols) are available on DOI 10.1594/PANGAEA.547989.

\section{Results}

Total organic carbon (TOC) content

In core BP99-04/7 (Fig. 4), maximum TOC values of $>1.6$ to almost $2 \%$ were dominant in the lower part between about 9.3 and 9 cal ka B.P., except for the two lowermost 
Table $1 \mathrm{AMS}^{14} \mathrm{C}$ datings of bivalves, performed at the Leibniz Laboratory, Kiel University

\begin{tabular}{|c|c|c|c|c|c|c|}
\hline Lab. no. & Depth $(\mathrm{cm})$ & AMS- ${ }^{14} \mathrm{C}$-uncorr. (years) & SE (years) & Res. corr. (years) & Age-corr. (years) & Cal. years B.P. \\
\hline \multicolumn{7}{|c|}{ Core BP99-04/7 } \\
\hline Surface & 0 & & & & 0 & 0 \\
\hline KIA23043* & 7 & 610 & 25 & -440 & 170 & 248 \\
\hline KIA-12781 & $29(59)$ & 1,630 & 20 & -440 & 1,190 & 1,159 \\
\hline KIA-12782 & $57(87)$ & 2,070 & 25 & -440 & 1,630 & 1,586 \\
\hline KIA23041 & $110(140)$ & 2,410 & 35 & -440 & 1,970 & 1,985 \\
\hline KIA-10239 & $122.5(152.5)$ & 2,430 & 30 & -440 & 1,990 & 2,001 \\
\hline KIA23042 & $163.5(193.5)$ & 3,380 & 30 & -440 & 2,940 & 3,203 \\
\hline KIA-10238 & $191(121)$ & 3,980 & 30 & -440 & 3,540 & 3,911 \\
\hline KIA-10237 & $246(276)$ & 4,695 & 30 & -440 & 4,255 & 4,847 \\
\hline KIA-10236 & $329(359)$ & 5,800 & 40 & -440 & 5,360 & 6,178 \\
\hline KIA-10235 & $420(450)$ & 6,855 & 35 & -440 & 6,415 & 7,325 \\
\hline KIA-10234 & 432 (462) & 6,890 & 45 & -440 & 6,450 & 7,373 \\
\hline KIA-10233 & $530(560)$ & 7,585 & 35 & -440 & 7,145 & 7,975 \\
\hline KIA-10232 & $632(662)$ & 8,345 & 50 & -440 & 7,905 & 8,845 \\
\hline KIA-10231 & $658.5(688.5)$ & 8,310 & 40 & -440 & 7,870 & 8,810 \\
\hline KIA-10230 & $700(730)$ & 8,725 & 40 & -440 & 8,285 & 9,059 \\
\hline \multicolumn{7}{|c|}{ Core BP00-07/7 } \\
\hline Surface & 0 & & & & 0 & 0 \\
\hline KIA14037 & 31 & 650 & 25 & -440 & 210 & 268 \\
\hline KIA14038 & 239 & 3,955 & 35 & -440 & 3,515 & 3,881 \\
\hline KIA14039 & 488 & 7,130 & 45 & -440 & 6,690 & 7,567 \\
\hline KIA14040 & 690 & 7,710 & 45 & -440 & 7,270 & 8,178 \\
\hline
\end{tabular}

Samples KIA23043*, KIA23041 and KIA23042 are from this study, all others from Stein et al. (2003a). The AMS ${ }^{14}$ C dates are $\delta^{13}$ C-normalized and corrected for a reservoir age of 440 years (Mangerud and Gulliksen 1975). Calendar years were calculated according to Stuiver et al. (1998). Because the uppermost $30 \mathrm{~cm}$ is missing in core BP99-04/7 due to overpenetration of the gravity corer, multicorer core BP99-04/4 was "set" on top of core BP99-04/7 (and depth values of core BP99-04/7 corrected by $+30 \mathrm{~cm}$ ). Sample KIA23043* is from the multicorer core.

samples with lower TOC values of 1 and $1.3 \%$. TOC contents of 1.3 to $1.6 \%$ occur between 9 and $7.7 \mathrm{cal} \mathrm{ka} \mathrm{B.P.}$ In the middle part of the core ( 7.7 to 2 cal ka B.P.), TOC values vary between 0.8 and $1.3 \%$, except for three peak values of $>1.5 \%$ near $7.5,5$ and 4.8 cal ka B.P. For the last 2 cal ka B.P., high TOC values of 1.3 to $1.5 \%$ are typical.

In core BP00-07/7 (Fig. 5), TOC values show a rather low variability ranging between 1 and $1.3 \%$. Only close to the surface was a higher value of $1.65 \%$ determined.

\section{Biomarker composition}

In order to interpret TOC records in terms of palaeoenvironmental significance, information about the composition of the organic matter is necessary. Using biomarker records of terrigenous biomarkers such as long-chain $n$ alkanes, campesterol, $\beta$-sitosterol, and long-chain fatty acids $(>\mathrm{C} 24)$ as well as the marine/fluvial biomarkers dinosterol and diatom-specific fatty acids, we obtained information about the origin of organic carbon fractions accumulated at the sites of cores BP99-04/7 and BP00-07/ 7. Furthermore, high CPI values of $>4$ were recorded in both cores (Tables 2 and 3), indicating the predominance of fresh, immature organic matter throughout.

In core BP99-04/7 (Fig. 4, Table 2), the terrigenous biomarker levels generally correlate well with the TOC record, except for the lowermost part of the record. Between 9.3 and 7.2 cal ka B.P., the $n$-alkanes, campesterol, and $\beta$-sitosterol decrease from 6 to $3 \mu \mathrm{g} \mathrm{g}_{\text {sed }}^{-1}, 0.3$ to $0.1 \mu \mathrm{g}$ $\mathrm{g}_{\text {sed }}^{-1}$, and 2.5 to $0.9 \mu \mathrm{g} \mathrm{g}_{\text {sed }}^{-1}$, respectively, and the terrigenous fatty acids vary between 8 and $5 \mu \mathrm{g} \mathrm{g} \mathrm{g}_{\text {sed }}^{-1}$. Between 7.2 and $2 \mathrm{cal}$ ka B.P., all terrigenous biomarkers show relatively low levels with little variability (Fig. 4). One exception is a maximum value which exists for all terrigenous biomarkers near $5 \mathrm{cal} \mathrm{ka}$ B.P. In the uppermost part of the core, the values increase slightly to $3.5 \mu \mathrm{g} \mathrm{g}_{\text {sed }}^{-1}$ for the long-chain $n$ alkanes, $0.15 \mu \mathrm{g} \mathrm{g}_{\text {sed }}^{-1}$ for campesterol, $1 \mu \mathrm{g} \mathrm{g} \mathrm{g}_{\text {sed }}^{-1}$ for $\beta$ sitosterol, and between 8 and $6 \mu \mathrm{g} \mathrm{g}_{\text {sed }}^{-1}$ for the terrigenous fatty acids. The percentage of terrigenous organic carbon is mostly higher than $80 \%$, with some lower values of $70 \%$ in the upper part of the record.

By contrast, the marine/fluvial biomarkers in core BP99$04 / 7$ show the lowest values in the lowermost part of the core (Fig. 4). Dinosterol values then increase from $0.1 \mu \mathrm{g}$ 


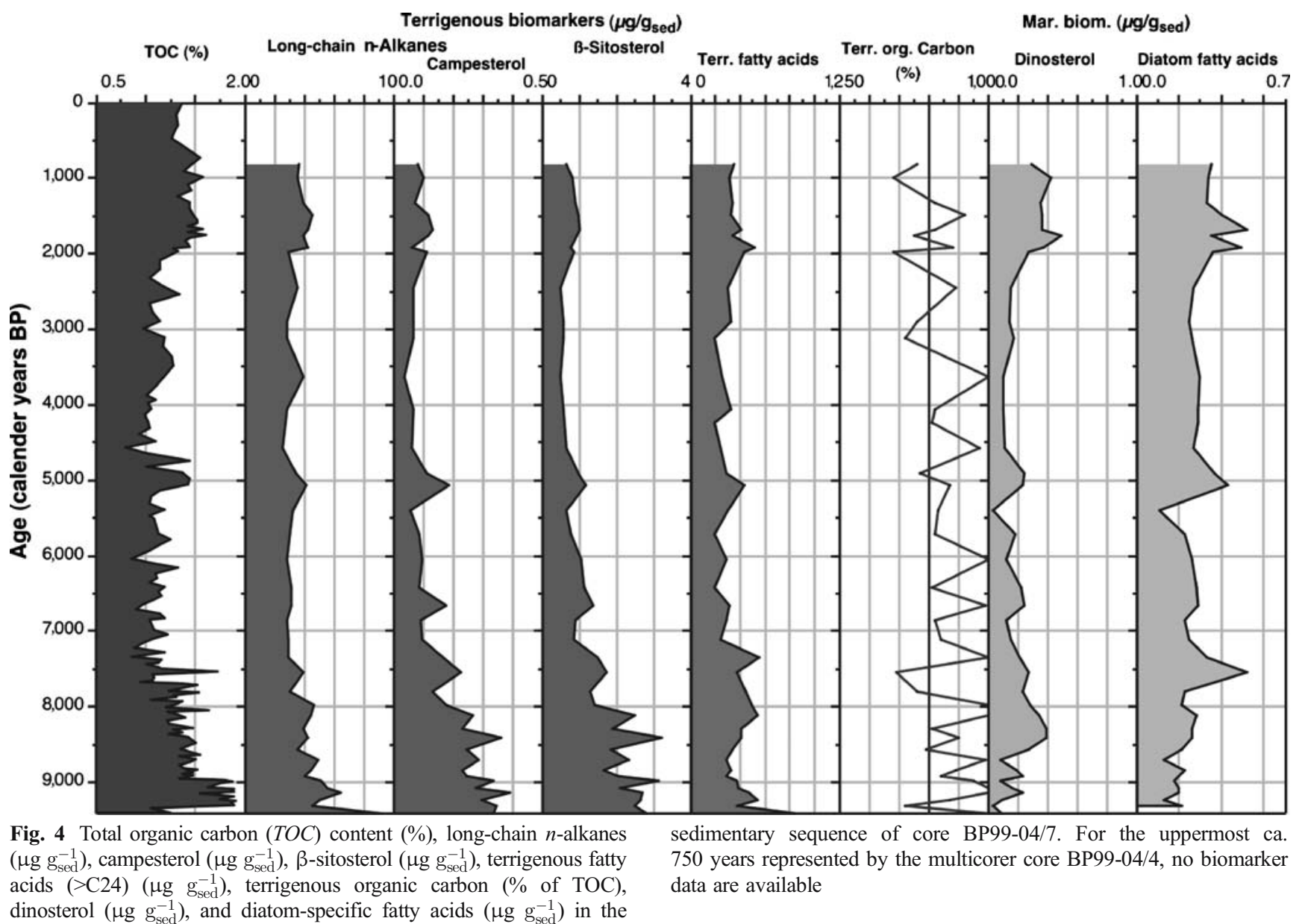

$\mathrm{g}_{\text {sed }}^{-1}$ to a maximum of $0.4 \mu \mathrm{g} \mathrm{g} \mathrm{g}_{\text {sed }}^{-1}$ at $8.3 \mathrm{cal} \mathrm{ka}$ B.P. Between 8.3 and 2 cal ka B.P., dinosterol values range from 0.1 to $0.25 \mu \mathrm{g} \mathrm{g}_{\text {sed }}^{-1}$. The diatom-specific fatty acids vary between 0.1 and $0.3 \mu \mathrm{g} \mathrm{g}_{\text {sed }}^{-1}$ in the time interval from 9.3 to 2 cal ka B.P., excepting for maxima of 0.5 and $0.4 \mu \mathrm{g} \mathrm{g}_{\text {sed }}^{-1}$ near 7.5 and $5 \mathrm{cal} \mathrm{ka} \mathrm{B.P.,} \mathrm{respectively.} \mathrm{In} \mathrm{the}$ last 2 cal ka B.P., both dinosterol and diatom-specific fatty acids increase significantly, reaching values of $0.3-0.5 \mu \mathrm{g}$ $\mathrm{g}_{\text {sed. }}^{-1}$.

In core BP00-07/7 (Fig. 5, Table 3), the contents of the terrigenous biomarkers do not show any clear longterm trends. The long-chain $n$-alkanes, campesterol, $\beta$ sitosterol and the terrigenous fatty acids vary between 2.1 and $3.5 \mu \mathrm{g} \mathrm{g}_{\text {sed }}^{-1}, 0.1$ and $0.5 \mu \mathrm{g} \mathrm{g}_{\text {sed }}^{-1}, 0.7$ and $2.2 \mu \mathrm{g} \mathrm{g}_{\text {sed }}^{-1}$, and 3 and $5.4 \mu \mathrm{g} \mathrm{g}_{\text {sed }}^{-1}$, respectively. The proportion of terrigenous organic carbon is less than that in core BP99$04 / 7$, reaching values between 50 and $80 \%$. The dinosterol record is characterized by high values of $1.5 \mu \mathrm{g} \mathrm{g} \mathrm{ged}_{\text {sed }}^{-1}$ at the bottom of the core, average values between 0.5 and $0.9 \mu \mathrm{g}$ $\mathrm{g}_{\text {sed }}^{-1}$ in the middle part, and contents increasing to $1.2 \mu \mathrm{g}$ $\mathrm{g}_{\text {sed }}^{-1}$ towards the top. The record of the diatom-specific fatty acids shows values of 0.2 to $0.7 \mu \mathrm{g} \mathrm{g}_{\text {sed }}^{-1}$ throughout the whole core, with one maximum value of $1.5 \mu \mathrm{g} \mathrm{g}_{\text {sed }}^{-1}$ in the uppermost sample of the core.

\section{Discussion}

Studies of surface sediments from the southern Kara Sea showed that organic geochemical bulk parameters and biomarkers are useful proxies to trace terrigenous organic carbon input into the Kara Sea (see Stein and Fahl 2004 and references therein). Based on results from these studies, the dominance of terrigenous organic matter is clearly indicated in the high absolute contents of long chain $n$-alkanes, which reach their maximum values in the Yenisei Estuary (Fig. 6). The generally good correlation between campesterol and $\beta$ sitosterol, i.e. sterols synthesized mainly by higher plants, and the long-chain $n$-alkanes (Fahl et al. 2003), as well as the light $\delta^{13} C_{\text {org }}$ values of about $-27 \%$ and high $\mathrm{C} / \mathrm{N}$ ratios exceeding 15 (Fernandes and Sicre 2000; Krishnamurthy et al. 2001; Stein and Fahl 2004) support a terrigenous origin of organic matter in the Yenesei Estuary surface sediments. The decrease in content of long chain $n$-alkanes towards the open Kara Sea indicates a relative decrease of terrigenous organic matter, as reflected also in the $\mathrm{C} / \mathrm{N}$ ratios (Fig. 6). Based on the $n$-alkane approach described above, these samples may contain 30-40\% marine organic carbon.

Using the $n$-alkane approach as well as the bulk and TOC accumulation rates determined in the two well-dated 


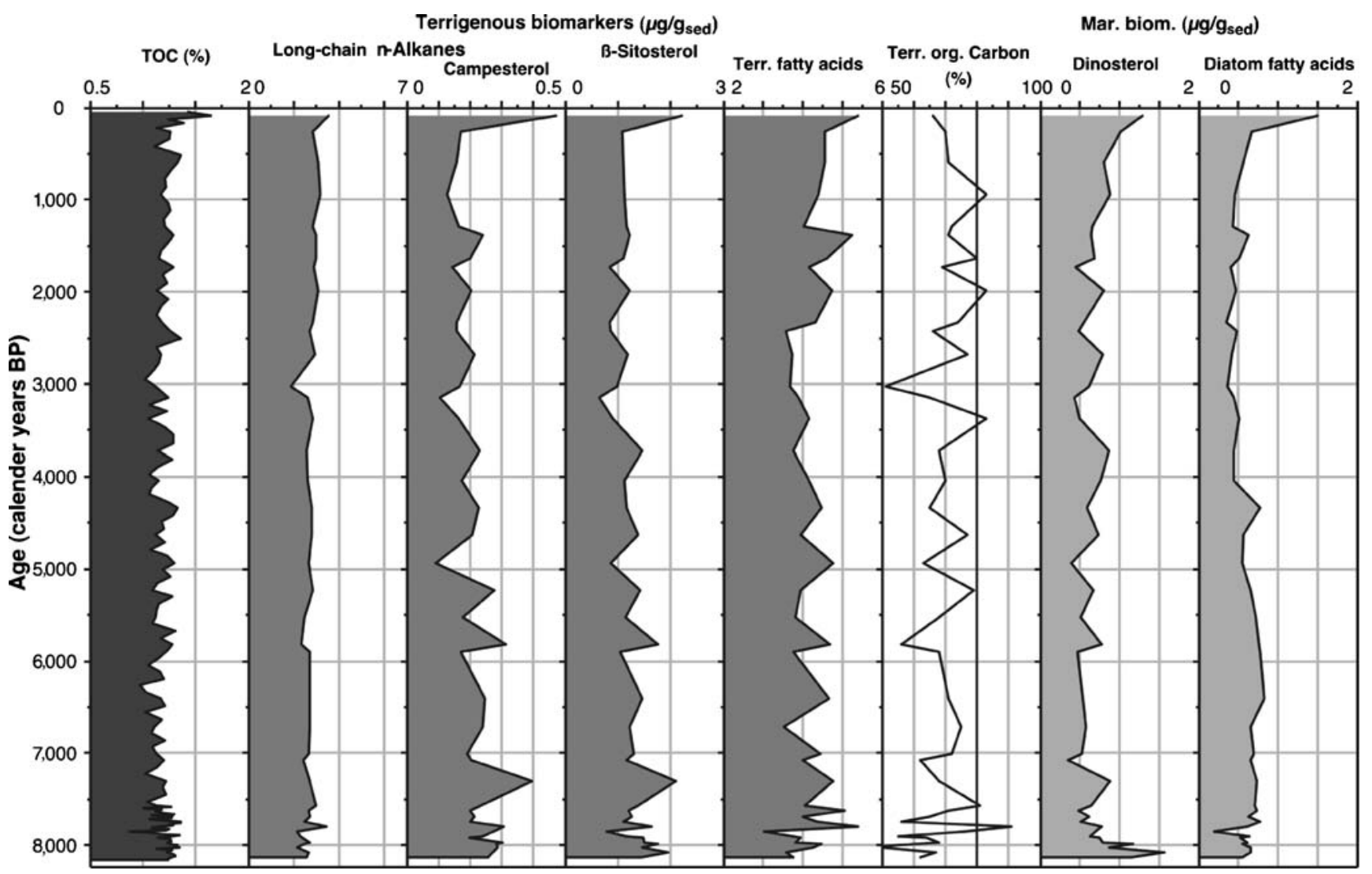

Fig. 5 Total organic carbon (TOC) content (\%), long-chain $n$-alkanes $\left(\mu \mathrm{g} \mathrm{g}_{\text {sed }}^{-1}\right)$, campesterol $\left(\mu \mathrm{g} \mathrm{g}_{\text {sed }}^{-1}\right), \beta$-sitosterol $\left(\mu \mathrm{g} \mathrm{g}_{\text {sed }}^{-1}\right)$, terrigenous fatty acids $(>\mathrm{C} 24)\left(\mu \mathrm{g} \mathrm{g}_{\text {sed }}^{-1}\right)$, terrigenous organic carbon $(\%$ of TOC),

dinosterol $\left(\mu \mathrm{g} \mathrm{g}_{\mathrm{sed}}^{-1}\right)$, and diatom-specific fatty acids $\left(\mu \mathrm{g} \mathrm{g}_{\mathrm{sed}}^{-1}\right)$ in the sedimentary sequence of core BP00-07/7

sediment cores BP99-04/7 and BP00-07/7, we were able to quantify terrigenous sediment and organic matter input into the southern Kara Sea and its change through Holocene times.

The most detailed record of changes in sediment accumulation during the last ca. 9 cal ka B.P. is available from core BP99-04/7. In this core, maximum bulk accumulation rates predominantly representing siliciclastic (riverine) material (Stein et al. 2003a, 2004) were recorded near the base of the core at $>8.8 \mathrm{cal}$ ka B.P. (Fig. 7). At the same time, magnetic susceptibility values were two to three times higher than for the subsequent Holocene interval, related to the final stage of mountain deglaciation of the Putoran Massif during Termination I and the subsequent release of huge amounts of fine-grained glacigenic debris enriched in ferrimagnetic minerals into the Yenisei River (Stein et al. 2003a, 2004). In the following time interval, the mean accumulation rates of bulk (terrigenous) sediments decreased continuously until about 4 cal ka B.P. (Fig. 7). The gradual decrease in accumulation rate between ca. 9 and $4 \mathrm{cal}$ ka B.P. is explained by a southward retreat of the river mouth and a landward migration of the centre of the "marginal filter" (i.e. the depocentre with maximum accumulation rates; see Stein et al. 2004), which directly followed sea-level rise, towards its present position. At about 9 cal ka B.P., the sea level was about $30 \mathrm{~m}$ lower than today (Fairbanks 1989). At that time, site BP99-04 was probably situated close to the mouth of the Yenisei, which is supported by the absence of marine organisms in the sediment (Kraus et al. 2003). This scenario is also in good agreement with the stepwise decrease in (freshwater) diatom accumulation rates observed in the sedimentary section of core BP99-04/7 (Polyakova and Stein 2004).

Superimposed on the general decrease in accumulation rates between 9 and $4 \mathrm{cal}$ ka B.P., a maximum was recorded between 7.3 and $8 \mathrm{cal}$ ka B.P. (Fig. 7). Almost exactly at the same time ( 7.5 to 8.2 cal ka B.P.), maximum accumulation rates were also recorded in core BP00-07/7 (Fig. 7). The absolute values in this core are even higher than those of core BP99-04, caused by the location of core BP00-07/7 within the centre of the "marginal filter" at that time of lowered sea level. This maximum in accumulation rates in both cores, which coincides with a distinct maximum in grain size of the siliciclastic material in core BP99-04 (Stein et al. 2004), is explained by distinctly inceased fluvial discharge between 7.3 and $8.2 \mathrm{cal}$ ka B.P. Higher contribution of river water between 7 and 8 cal ka B.P. is also supported by the very low $\delta^{18} \mathrm{O}$ values determined in 
Table 2 Data on total organic carbon (TOC) content, long-chain $n$-alkanes, terrigenous fatty acids ( $>$ C24), campesterol, $\beta$-sitosterol, dinosterol, diatom-specific fatty acids, and carbon preference index (CPI) for core BP99-04/7

\begin{tabular}{|c|c|c|c|c|c|c|c|c|}
\hline $\begin{array}{l}\text { Depth } \\
(\mathrm{cm})\end{array}$ & $\begin{array}{l}\text { TOC } \\
(\%)\end{array}$ & $\begin{array}{l}\text { Long-chain } n \text { - } \\
\text { alkanes }\left(\mu g_{\mathrm{sed}}^{-1}\right)\end{array}$ & $\begin{array}{l}\text { Campesterol } \\
\left(\mu g g_{\text {sed }}^{-1}\right)\end{array}$ & $\begin{array}{l}\beta \text {-Sitosterol } \\
\left(\mu \mathrm{g} \mathrm{g}_{\mathrm{sed}}^{-1}\right)\end{array}$ & $\begin{array}{l}\text { Long-chain fatty } \\
\left.\text { acids ( } \mu \mathrm{g} \mathrm{g}_{\mathrm{sed}}^{-1}\right)\end{array}$ & $\begin{array}{l}\text { Dinosterol } \\
\left(\mu \mathrm{g} \mathrm{g}_{\mathrm{sed}}^{-1}\right)\end{array}$ & $\begin{array}{l}\text { Diatom fatty } \\
\text { acids }\left(\mu \mathrm{g} \mathrm{g}_{\mathrm{sed}}^{-1}\right)\end{array}$ & CPI \\
\hline 0 & 1.39 & & & & & & & \\
\hline 10 & 1.49 & 3.68 & 0.08 & 0.66 & 6.58 & 0.29 & 0.35 & 4.3 \\
\hline 20 & 1.60 & 3.57 & 0.10 & 0.83 & 6.12 & 0.42 & 0.34 & 3.9 \\
\hline 40 & 1.46 & 3.92 & 0.07 & 0.90 & 6.40 & 0.35 & 0.33 & 4.2 \\
\hline 50 & 1.50 & 4.51 & 0.12 & 0.96 & 6.27 & 0.36 & 0.40 & 4.4 \\
\hline 70 & 1.60 & 4.25 & 0.13 & 1.03 & 7.08 & 0.36 & 0.52 & 4.3 \\
\hline 80 & 1.62 & 3.99 & 0.12 & 0.95 & 6.45 & 0.49 & 0.35 & 4.0 \\
\hline 100 & 1.46 & 4.21 & 0.06 & 0.77 & 8.19 & 0.37 & 0.49 & 4.4 \\
\hline 110 & 1.35 & 2.99 & 0.11 & 0.86 & 7.38 & 0.27 & 0.36 & 4.2 \\
\hline 130 & 1.20 & 3.51 & 0.07 & 0.48 & 6.02 & 0.15 & 0.27 & 4.7 \\
\hline 150 & 1.16 & 2.89 & 0.07 & 0.57 & 6.26 & 0.15 & 0.25 & 4.3 \\
\hline 160 & 1.21 & 2.81 & 0.07 & 0.58 & 5.02 & 0.17 & 0.26 & 4.4 \\
\hline 180 & 1.20 & 3.91 & 0.04 & 0.49 & 5.61 & 0.10 & 0.30 & 3.0 \\
\hline 200 & 1.07 & 2.88 & 0.07 & 0.58 & 6.25 & 0.10 & 0.29 & 4.5 \\
\hline 210 & 1.05 & 2.76 & & & 5.02 & & 0.29 & 4.5 \\
\hline 230 & 0.81 & 2.57 & 0.06 & 0.65 & 5.49 & 0.12 & 0.27 & 4.6 \\
\hline 250 & 1.39 & 3.48 & 0.11 & 0.99 & 5.88 & 0.25 & 0.37 & 4.6 \\
\hline 260 & 1.44 & 4.10 & 0.19 & 1.16 & 7.43 & 0.23 & 0.43 & 4.7 \\
\hline 280 & 1.20 & 3.26 & 0.06 & 0.66 & 6.00 & 0.04 & 0.11 & 4.7 \\
\hline 300 & 1.14 & 3.04 & 0.09 & 0.78 & 4.93 & 0.18 & 0.23 & 4.6 \\
\hline 321 & 0.87 & 2.83 & 0.10 & 1.08 & 5.90 & 0.12 & 0.26 & 4.8 \\
\hline 350 & 1.20 & 3.19 & 0.09 & 1.12 & 4.96 & 0.22 & 0.28 & 4.4 \\
\hline 370 & 0.98 & 3.16 & 0.18 & 1.39 & 6.21 & 0.25 & 0.29 & 4.5 \\
\hline 390 & 1.05 & 2.83 & 0.09 & 0.89 & 5.96 & 0.13 & 0.23 & 4.6 \\
\hline 410 & 1.08 & 2.95 & 0.10 & 0.88 & 5.50 & 0.16 & 0.25 & 4.7 \\
\hline 430 & 0.87 & 2.99 & 0.17 & 1.50 & 8.56 & 0.22 & 0.33 & 4.5 \\
\hline 460 & 1.75 & 3.94 & 0.23 & 1.73 & 6.81 & 0.28 & 0.52 & 4.9 \\
\hline 500 & 1.25 & 3.07 & 0.13 & 1.30 & 7.49 & 0.23 & 0.23 & 4.5 \\
\hline 530 & 1.33 & 4.65 & 0.18 & 1.40 & 7.92 & 0.29 & 0.21 & 5.2 \\
\hline 550 & 1.35 & 4.46 & 0.27 & 2.48 & 8.44 & 0.35 & 0.28 & 4.8 \\
\hline 572 & 1.49 & 3.96 & 0.23 & 1.92 & 7.09 & 0.40 & 0.26 & 4.7 \\
\hline 590 & 1.45 & 4.25 & 0.36 & 3.20 & 7.10 & 0.40 & 0.26 & 4.6 \\
\hline 610 & 1.37 & 3.52 & 0.25 & 1.87 & 6.41 & 0.27 & 0.21 & 4.7 \\
\hline 630 & 1.53 & 4.94 & 0.29 & 2.33 & 5.99 & 0.09 & 0.13 & 5.0 \\
\hline 650 & 1.54 & 4.45 & 0.23 & 1.64 & 6.26 & 0.19 & 0.23 & 5.0 \\
\hline 670 & 1.49 & 4.09 & 0.25 & 2.04 & 5.91 & 0.24 & & 5.0 \\
\hline 680 & 1.66 & 5.13 & 0.34 & 3.14 & 6.82 & 0.09 & 0.18 & 5.5 \\
\hline 700 & 1.64 & 5.51 & 0.28 & 2.09 & 6.89 & 0.16 & 0.20 & 5.6 \\
\hline 720 & 1.92 & 6.45 & 0.39 & 2.72 & 7.78 & 0.23 & 0.20 & 5.7 \\
\hline 740 & 1.77 & 5.00 & 0.30 & 2.65 & 8.48 & 0.09 & 0.13 & 6.1 \\
\hline 760 & 1.91 & 4.50 & 0.35 & 2.50 & 6.73 & 0.03 & 0.21 & 6.3 \\
\hline 780 & 1.27 & 9.26 & 0.34 & 2.83 & 11.56 & 0.09 & & 6.1 \\
\hline
\end{tabular}

ostracods in core BP00-07/5 (Simstich et al. 2004). Between 7.5 and 8 cal ka B.P., maxima in accumulation rates of both freshwater and marine diatoms were recorded in core BP99-04/7, interpreted as an increase in marine productivity due to enhanced riverine nutrient supply (Polyakova and Stein 2004). At 7.5 cal ka B.P., the diatom-specific fatty acids reach a maximum, too (Fig. 4). This period between 7 and 8 cal ka B.P. correlates with the "mid-Holocene Climatic Optimum" characterized by warm- er and moister climate in Siberia (e.g. Andreev and Klimanov 2000; Andreev et al. 2002), resulting in high river runoff rates. An early Holocene warming trend culminating in a temperature maximum between 7.8 and 6.8 cal ka B.P., and characterized by increased Atlantic water inflow, has also been recorded in a sediment core from the northernmost Barents Sea (Duplessy et al. 2001). A very similar evolution has been described for the history of river discharge in the Laptev Sea (Bauch et al. 2001a,b). 
Table 3 Data on total organic carbon (TOC) content, long-chain $n$-alkanes, terrigenous fatty acids ( $>$ C24), campesterol, $\beta$-sitosterol, dinosterol, diatom-specific fatty acids, and carbon preference index (CPI) for core BP00-07/7

\begin{tabular}{|c|c|c|c|c|c|c|c|c|}
\hline $\begin{array}{l}\text { Depth } \\
(\mathrm{cm})\end{array}$ & $\begin{array}{l}\text { TOC } \\
(\%)\end{array}$ & $\begin{array}{l}\text { Long-chain } n \text { - } \\
\text { alkanes }\left(\mu g_{\text {sed }}^{-1}\right)\end{array}$ & $\begin{array}{l}\text { Campesterol } \\
\left(\mu \mathrm{g} \mathrm{g}_{\mathrm{sed}}^{-1}\right)\end{array}$ & $\begin{array}{l}\beta \text {-Sitosterol } \\
\left(\mu \mathrm{g} \mathrm{g}_{\text {sed }}^{-1}\right)\end{array}$ & $\begin{array}{l}\text { Long-chain fatty } \\
\left.\text { acids ( } \mu \mathrm{g} \mathrm{g}_{\text {sed }}^{-1}\right)\end{array}$ & $\begin{array}{l}\text { Dinosterol } \\
\left(\mu \mathrm{g} \mathrm{g}_{\text {sed }}^{-1}\right)\end{array}$ & $\begin{array}{l}\text { Diatom fatty } \\
\text { acids }\left(\mu g_{\mathrm{sed}}^{-1}\right)\end{array}$ & $\mathrm{CP}$ \\
\hline 0 & 1.70 & & & & & & & \\
\hline 10 & 1.65 & 3.54 & 0.47 & 2.22 & 5.41 & 1.30 & 1.50 & 4.2 \\
\hline 30 & 1.26 & 2.86 & 0.17 & 1.09 & 4.56 & 1.01 & 0.67 & 4.0 \\
\hline 50 & 1.33 & 3.08 & 0.16 & 0.93 & 4.55 & 0.80 & 0.56 & 4.1 \\
\hline 70 & 1.17 & 3.18 & 0.13 & 1.11 & 4.39 & 0.88 & 0.46 & 4.2 \\
\hline 90 & 1.21 & 2.85 & 0.17 & 1.15 & 4.03 & 0.66 & 0.43 & 4.1 \\
\hline 95 & 1.29 & 2.98 & 0.24 & 1.22 & 5.25 & 0.64 & 0.63 & 4.1 \\
\hline 110 & 1.15 & 3.00 & 0.20 & 1.10 & 4.6 & 0.69 & 0.51 & 4.3 \\
\hline 115 & 1.29 & 2.90 & 0.14 & 0.85 & 4.16 & 0.44 & 0.41 & 4.2 \\
\hline 130 & 1.13 & 3.08 & 0.20 & 1.21 & 4.73 & 0.80 & 0.47 & 4.3 \\
\hline 150 & 1.18 & 2.86 & 0.16 & 0.85 & 4.33 & 0.55 & 0.35 & 4.3 \\
\hline 155 & 1.26 & 2.72 & 0.16 & 0.86 & 3.58 & 0.48 & 0.49 & 4.3 \\
\hline 170 & 1.17 & 2.95 & 0.21 & 1.18 & 3.74 & 0.78 & 0.42 & 4.3 \\
\hline 190 & 1.12 & 1.88 & 0.17 & 0.99 & 3.68 & 0.62 & 0.36 & 3.9 \\
\hline 197 & 1.24 & 2.63 & 0.10 & 0.65 & 3.89 & 0.43 & 0.45 & 4.2 \\
\hline 210 & 1.05 & 2.83 & 0.16 & 0.91 & 4.15 & 0.50 & 0.51 & 3.9 \\
\hline 230 & 1.14 & 2.55 & 0.23 & 1.45 & 3.76 & 0.86 & 0.45 & 4.0 \\
\hline 250 & 1.15 & 2.62 & 0.17 & 1.13 & 4.15 & 0.76 & 0.45 & 4.2 \\
\hline 270 & 1.33 & 2.80 & 0.23 & 1.17 & 4.48 & 0.58 & 0.77 & 4.3 \\
\hline 290 & 1.12 & 2.80 & 0.21 & 1.38 & 3.96 & 0.74 & 0.56 & 4.3 \\
\hline 310 & 1.30 & 2.65 & 0.09 & 0.87 & 4.77 & 0.40 & 0.55 & 4.3 \\
\hline 330 & 1.09 & 2.83 & 0.28 & 1.41 & 3.94 & 0.67 & 0.66 & 4.3 \\
\hline 350 & 1.13 & 2.49 & 0.18 & 1.14 & 3.81 & 0.51 & 0.72 & 4.3 \\
\hline 370 & 1.28 & 2.35 & 0.31 & 1.75 & 4.69 & 0.78 & 0.76 & 4.3 \\
\hline 375 & 1.22 & 2.71 & 0.17 & 1.04 & 3.75 & 0.47 & 0.78 & 4.3 \\
\hline 410 & 1.17 & 2.72 & 0.25 & 1.47 & 4.65 & 0.53 & 0.83 & 4.3 \\
\hline 430 & 1.11 & 2.72 & 0.24 & 1.23 & 3.51 & 0.57 & 0.65 & 4.3 \\
\hline 450 & 1.14 & 2.66 & 0.19 & 1.30 & 4.46 & 0.53 & 0.70 & 4.4 \\
\hline 455 & 1.20 & 2.44 & 0.20 & 1.16 & 4.01 & 0.36 & 0.66 & 4.4 \\
\hline 470 & 1.23 & 2.72 & 0.40 & 2.1 & 4.78 & 0.89 & 0.74 & 4.3 \\
\hline 490 & 1.13 & 2.98 & 0.23 & 1.38 & 4.06 & 0.64 & 0.71 & 4.4 \\
\hline 510 & 1.16 & 2.68 & 0.20 & 1.21 & 5.06 & 0.48 & 0.73 & 4.3 \\
\hline 530 & 1.28 & 2.72 & 0.21 & 1.26 & 4.00 & 0.62 & 0.63 & 4.4 \\
\hline 550 & 1.36 & 2.48 & 0.20 & 1.10 & 4.37 & 0.51 & 0.78 & 4.1 \\
\hline 570 & 1.16 & 3.45 & 0.31 & 1.64 & 5.40 & 0.77 & 0.62 & 4.3 \\
\hline 590 & 0.87 & 2.17 & & 0.79 & 3.02 & 0.69 & 0.19 & 4.7 \\
\hline 610 & 1.27 & 2.28 & 0.24 & 1.17 & 3.76 & 0.63 & 0.64 & 4.3 \\
\hline 615 & 1.14 & 2.40 & 0.20 & 1.47 & 3.94 & 0.75 & 0.52 & 4.4 \\
\hline 630 & 1.23 & 2.72 & 0.30 & 1.51 & 3.82 & 0.79 & 0.61 & 4.4 \\
\hline 635 & 1.25 & 2.49 & 0.28 & 1.76 & 4.47 & 1.17 & 0.55 & 4.3 \\
\hline 650 & 1.35 & 2.15 & 0.29 & 1.46 & 4.27 & 0.86 & 0.66 & 4.2 \\
\hline 670 & 1.23 & 2.66 & & 1.96 & 3.57 & 1.57 & 0.65 & 4.4 \\
\hline 690 & 1.27 & 2.55 & 0.26 & 1.43 & 3.76 & 1.15 & 0.55 & 4.3 \\
\hline
\end{tabular}

Near 2 cal ka B.P., another increase in accumulation rates was recorded at site BP99-04 (Fig. 7). This change coincided with a distinct decrease in grain size and magnetic susceptibility, interpreted as reduced current velocity and reduced river discharge (Stein et al. 2004). Under these conditions, increased amounts of fine-grained sediments accumulated in the estuary, as indicated by the elevated accumulation rates, and organic matter became enriched in the finer-grained sediments, indicated by the elevated TOC values (Fig. 4) as well as higher accumulation rates of organic carbon (Fig. 7). This increase in accumulation rates is not observed in core BP00-07/7 (Fig. 7) located outside (i.e. north of) the estuary.

The records of accumulation rates of total organic carbon show trends very similar to those of bulk (siliciclastic) sediments (Fig. 7), already supporting the predominantly 
Fig. 6 Distribution of $\mathrm{C} / \mathrm{N}$ ratios and long-chain $n$-alkanes $\left(\mu \mathrm{g} \mathrm{g}_{\text {sed }}^{-1}\right)$ in surface sediments from the Yenisei Transect (based on Fahl et al. 2003)

\section{Yenisei Transect "Marginal filter"}

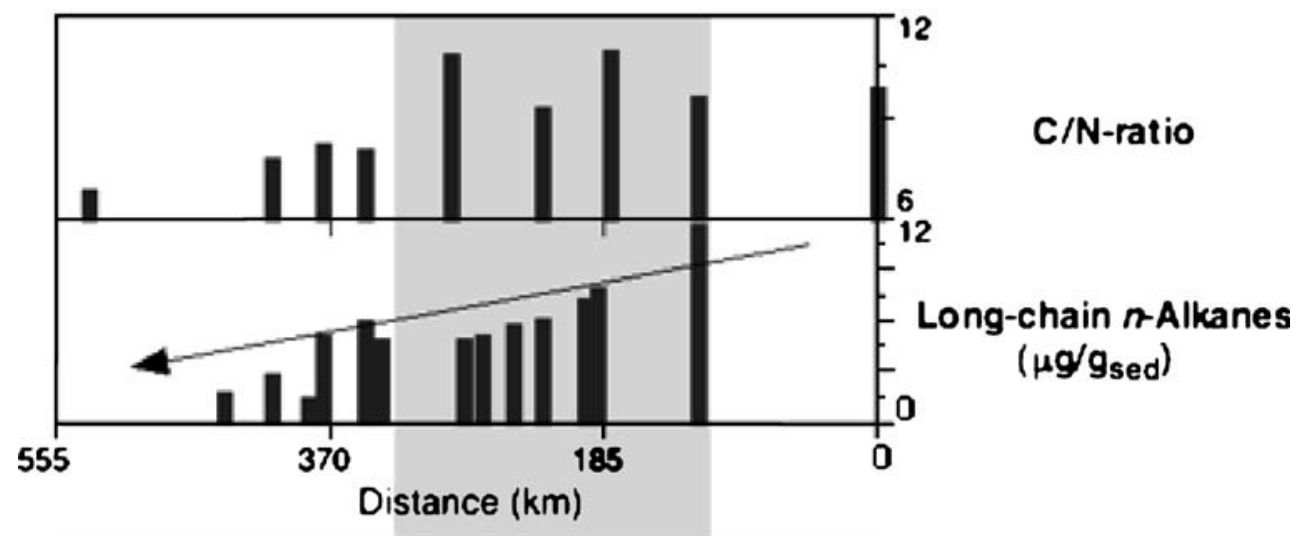

terrigenous source of the organic matter. The terrigenous source of the organic matter is proven by the biomarker data. The absolute amounts of terrigenous biomarkers (long-chain $n$-alkanes, campesterol, $\beta$-sitosterol, and longchain fatty acids) clearly parallel the TOC record of core BP99-04/7 (Fig. 4). Based on $n$-alkane data, about 70
$100 \%$ of the organic matter is of terrigenous origin, the higher values of $80-100 \%$ (average of $90 \%$ ) being more typical between 9.2 and $3.5 \mathrm{cal}$ ka B.P. and the lower values of $70-90 \%$ (average of $80 \%$ ) more typical for the last 3.5 cal ka B.P. (Fig. 4). In core BP00-07/7, i.e. towards the open Kara Sea, absolute contents of terrigenous biomarkers

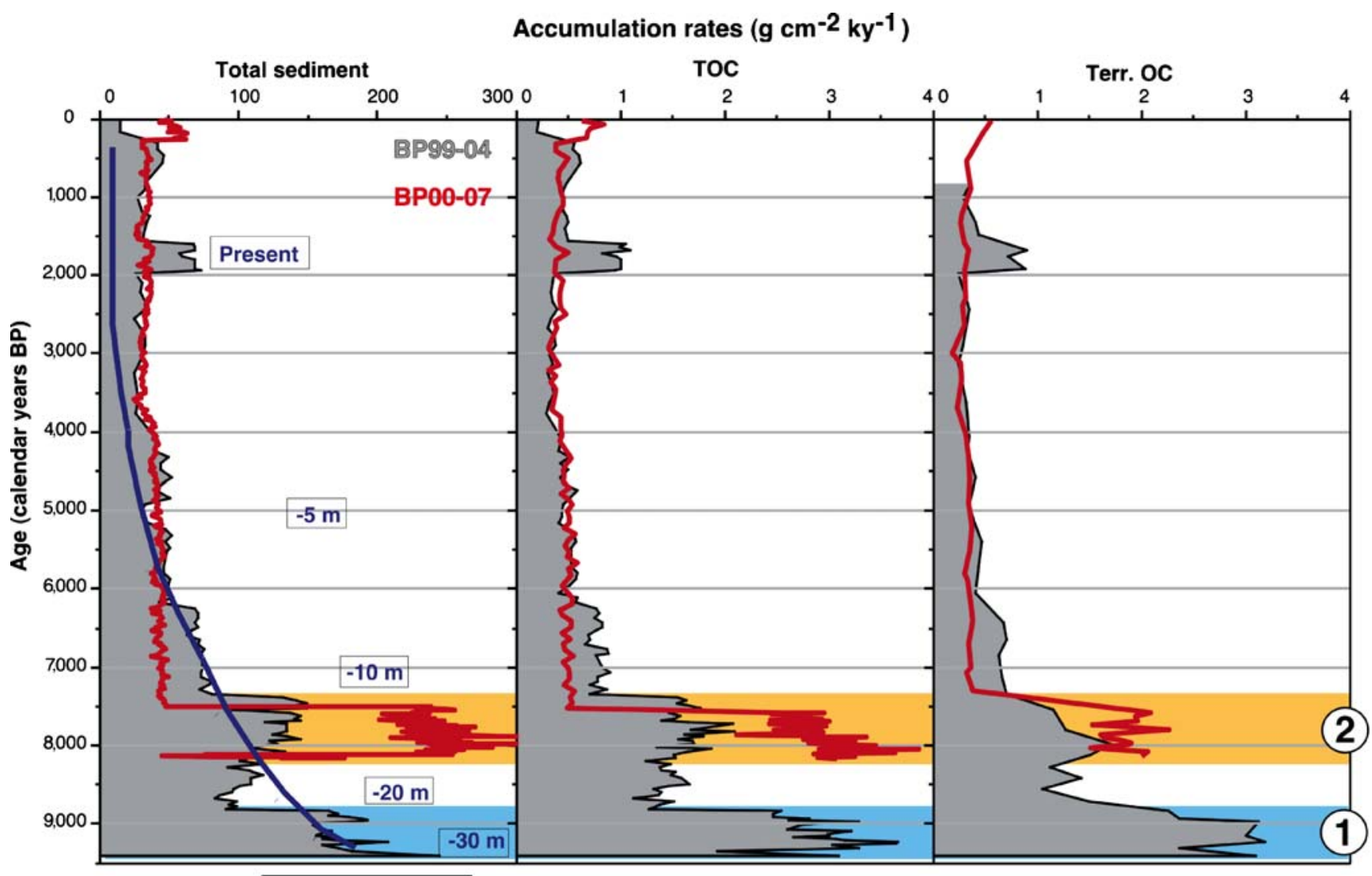

Global sea level

Fig. 7 Accumulation rate records of bulk (siliciclastic) sediments, total organic carbon, and terrigenous organic carbon from the AMS- ${ }^{14} \mathrm{C}$ dated cores BP99-04/07 (grey-shaded) and BP00-07/07 (red line). The blue bar (event 1) and the orange bar (event 2) indicate the periods of final deglaciation of the Putoran Massif and the midHolocene Climatic Optimum, respectively (see text for references). The global sea-level curve of Fairbanks (1989) is marked as a blue line 
decrease, indicating the decreased (increased) terrigenous (marine) influence (Fig. 5). Based on $n$-alkane data, 50$80 \%$ of the organic matter is of terrigenous origin in the sediments of core BP00-07/7. The maximum accumulation rates of terrigenous organic matter in both cores between about 7.3 and $8.2 \mathrm{cal}$ ka B.P., i.e. during the "mid-Holocene Climatic Optimum," also suggest more humid climatic conditions with an increased vegetation cover in the source area at that time (see Andreev and Klimanov 2000; Andreev et al. 2002).

During the last ca. 2 cal ka B.P., the contents of both terrigenous biomarkers (i.e. long-chain $n$-alkanes, $\beta$-sitosterol, and campesterol) and of marine biomarkers (i.e. dinosterol and diatom-specific fatty acids) increase in the northern Yenisei Estuary (Fig. 4), suggesting an enhanced effectiveness of the "marginal filter" as sediment trap at times of reduced river discharge. Due to increased flocculation/coagulation of fine-grained siliciclastic material ("ballast effect"; Ittekkot et al. 1992; Knies and Stein 1998), the vertical flux of (terrigenous and marine) organic matter to the seafloor within aggregates became more efficient, and even the more labile marine organic matter was preserved in the sediments.

This final decrease in river discharge and increase in accumulation of organic carbon in the Yenisei Estuary seem to correlate with a decline in precipitation in the Lake Baikal region (Vorobyeva 1994) which, via the Angara River, is one of the major water sources to the Yensei River. This trend is likely related to "sub-Atlantic cooling" in subArctic regions, and the development of modern vegetation zones in coastal and near-coastal areas of the Kara Sea (e.g. Velichko et al. 1997; Andreev and Klimanov 2000; Kraus et al. 2003). Contemporaneously, other global/regional climate changes are observed, including a cooling trend over Greenland as indicated in the GISP-2 Ice Core (Grootes et al. 1993), extended sea-ice cover in the North Atlantic (Andrews et al. 2001), and advances of glaciers in western Norway (Nesje et al. 2001).

\section{Conclusions}

- This study of accumulation rates and biomarker composition carried out on two well-dated sediment cores from the Yenisei Estuary in the southern Kara Sea gives information on organic carbon fluxes, Yenisei River discharge and climate change through Holocene times.

- Terrigenous organic carbon fluxes are predominant throughout, reaching $>50$ to $100 \%$ of the total organic carbon pool.

- The mid-Holocene Climate Optimum is reflected in the studied sediment cores by a prominent maximum of siliciclastic and terrigenous organic carbon accumulation between 7.3 and $8.2 \mathrm{cal}$ ka B.P., related to increased river discharge.

- During the last 2,000 years, river discharge decreased, and increased efficiency of coagulation processes of fine-grained siliciclastic material resulted in significantly enhanced accumulation/preservation of both marine and terrigenous organic matter.

Acknowledgements This study was performed within the joint German-Russian multidisciplinary research project on "Siberian River Run-off (SIRRO)." Comments by the two reviewers Phil Meyers and Matthias Zabel are much appreciated. Financial support by the German Ministry of Education, Science, Research and Technology (BMBF) is gratefully acknowledged.

\section{References}

Aagaard K, Carmack EC (1989) The role of sea ice and other fresh water in the Arctic circulation. J Geophys Res 94(C10):1448514498

Ackman RG, Tocher CS, McLachlan J (1968) Marine phytoplankter fatty acids. J Fish Res Board Can 25:1603-1620

Andreev AA, Klimanov VA (2000) Quantitative Holocene climatic reconstruction from Arctic Russia. J Paleolimnol 24:81-91

Andreev AA, Siegert C, Klimanov VA, Derevyagin AYu, Shilova GN, Melles M (2002) Late Pleistocene and Holocene vegetation and climate on Taymyr Lowland, Northern Siberia. Quat Res 57:138150

Andrews JT, Helgadottir G, Geirsdottir A, Jennings AE (2001) Multicentury-scale records of carbonate (hydrographic?) variability on the northern Iceland margin over the last 5000 years. Quat Res 56:199-206

Bauch HA, Kassens H, Naidina OD, Kunz-Pirrung M, Thiede J (2001a) Composition and flux of Holocene sediments on the eastern Laptev Sea shelf, Arctic Siberia. Quat Res 55:344-351

Bauch HA, Mueller-Lupp T, Taldenkova E, Spielhagen RF, Kassens H, Grootes PM, Thiede J, Heinemeier J, Petryashov VV (2001b) Chronology of the Holocene transgression at the North Siberian margin. Global Planet Change 31:125-139

Brassell SC, Eglinton G, Maxwell JR, Philip RP (1978) Natural background of alkanes in the aquatic environment. In: Hutzinger O, Lelyveld IH, Zoetman BCJ (eds) Aquatic pollutants: transformation and biological effects. Pergamon, Oxford, pp 69-86

Bray EE, Evans ED (1961) Distribution of $n$-paraffins as a clue to recognition of source beds. Geochim Cosmochim Acta 22:2-15

Christie WW (1990) Methylation of fatty acids. Lipid Technol 2:4849, 79-80

Conte MH, Eglinton G, Madureira LAS (1992) Long-chain alkenones and alkyl alkenoates as palaeotemperature indicators: their production, flux and early sedimentary diagenesis in the Eastern North Atlantic. Org Geochem 19(1/3):287-298

de Leeuw JW, Rijpstra WIC, Schenck PA, Volkman JK (1983) Free, esterified, and residual bound sterols in Black Sea Unit I sediments. Geochim Cosmochim Acta 47:455-465

Dittmers K, Niessen F, Stein R (2003) Holocene sediment budget and sedimentary history for the $\mathrm{Ob}$ and Yenisei estuaries. In: Stein $\mathrm{R}$, Fahl K, Fütterer DK, Galimov EM, Stepanets OV (eds) Siberian river run-off in the Kara Sea: characterisation, quantification, variability, and environmental significance. Proceedings in Marine Sciences, vol 6. Elsevier, Amsterdam, pp 457-484 
Duplessy JC, Ivanova E, Murdmaa I, Paterne M, Labeyrie L (2001) Holocene paleoceanography of the northern Barents Sea and variations of the northward heat transport by the Atlantic Ocean. Boreas 30:2-16

Duzhikov OA, Strunin BM (1992) Geological outline of the Norilisk region. In: Duzhikov OA, Strunin BM (eds) Geology and metallogeny of sulfide deposits, Norilisk region. USSR SEG Spec, Moscow, pp 1-60

Fahl K, Kattner G (1993) Lipid content and fatty acid composition of algal communities in sea-ice and water from Weddell Sea (Antarctica). Polar Biol 13:405-409

Fahl K, Stein R (1997) Modern organic-carbon-deposition in the Laptev Sea and the adjacent continental slope: surface-water productivity vs. terrigenous input. Org Geochem 26:379-390

Fahl K, Stein R (1999) Biomarkers as organic-carbon-source and environmental indicators in the Late Quaternary Arctic Ocean: "problems and perspectives". Mar Chem 63:293-309

Fahl K, Cremer H, Erlenkeuser H, Hanssen H, Hölemann J, Kassens H, Knickmeier K, Kosobokova K, Kunz-Pirrung M, Lindemann F, Markhaseva E, Lischka S, Petryashov V, Piepenburg D, Schmid M, Spindler M, Stein R, Tuschling K (2001) Sources and pathways of organic carbon in the modern Laptev Sea (Arctic Ocean): implications from biological, geochemical and geological data. Polarforschung 69(1999):193-205

Fahl K, Stein R, Gaye-Haake B, Gebhardt C, Kodina LA, Unger D, Ittekkot V (2003) Biomarkers in surface sediments from the $\mathrm{Ob}$ and Yenisei estuaries and southern Kara Sea: Evidence for particulate organic carbon sources, pathways, and degradation. In: Stein R, Fahl K, Fütterer DK, Galimov EM, Stepanets OV (eds) Siberian river run-off in the Kara Sea: characterisation, quantification, variability, and environmental significance. Proceedings in Marine Sciences, vol 6. Elsevier, Amsterdam, pp 329-348

Fairbanks RG (1989) A 17000-year glacio eustatic sea level record: influence of glacial meting rates on the Younger Dryas event and deep-ocean circulation. Nature 342:637-642

Fernandes MB, Sicre MA (2000) The importance of terrestrial organic carbon inputs on Kara Sea shelves as revealed by n-alkanes, OC and $\delta^{13} \mathrm{C}$ values. Org Geochem 31:363-374

Gordeev VV, Martin JM, Sidorov IS, Sidorova MV (1996) A reassessment of the Eurasian river input of water, sediment, major elements, and nutrients to the Arctic Ocean. Am J Sci 296:664-691

Grootes PM, Stuiver M, White JW, Johnson S, Jouzel J (1993) Comparison of oxygen isotope records from the GISP2 and GRIP Greenland ice cores. Nature 366:552-554

Hollerbach A (1985) Grundlagen der organischen Geochemie. Springer, Berlin Heidelberg New York

Holmes RM, McClelland JW, Peterson BJ, Shiklomanov AI, Zhulidov AV, Gordeev VV, Bobrovitskaya N (2002) A circumpolar perspective on fluvial sediment flux to the Arctic Ocean. Global Biogeochem Cycles 16/4. DOI 10.1029/2002GB001920

Huang W-Y, Meinschein WG (1976) Sterols as source indicators of organic materials in sediments. Geochim Cosmochim Acta 40 (3):323-330

Ittekkot V, Haake B, Bartsch M, Nair RR, Ramaswamy V (1992) Organic carbon removal in the sea: the continental connection. In: Summerhayes CP, Prell WL, Emeis KC (eds) Upwelling systems: evolution since the early Miocene. Geological Society, London, Geol Soc Spec, pp 167-176

Kates K, Volcani BE (1966) Lipid components of diatoms. Biochem Biophys Acta 116:264-278

Kattner G, Gercken G, Eberlein K (1983) Development of lipids during a spring plankton bloom in the Northern North Sea. I. Particulate fatty acids. Mar Chem 14:149-162
Knies J, Stein R (1998) New aspects of organic carbon deposition and its paleoceanographic implications along the northern Barents Sea margin during the last 30,000 years. Paleoceanography 13:384-394

Kraus M, Matthiessen J, Stein R (2003) A high-resolution Holocene marine pollen record from the northern Yenisei Estuary (southeastern Kara Sea) and paleoenvironmental implications. In: Stein R, Fahl K, Fütterer DK, Galimov EM, Stepanets OV (eds) Siberian river run-off in the Kara Sea: characterisation, quantification, variability, and environmental significance. Proceedings in Marine Sciences, vol 6. Elsevier, Amsterdam, pp 435-456

Krishnamurthy RV, Machavaram M, Baskaran M, Brooks JM, Champs MA (2001) Organic carbon flow in the Ob, Yenisei rivers and Kara Sea of the Arctic Region. Mar Pollut Bull 42:726-732

Lisitzin AP (1995) The marginal filter of the ocean. Oceanology 34 (5):671-682

Mangerud J, Gulliksen S (1975) Apparent radiocarbon ages of recent marine shells from Norway, Spitsbergen, and Arctic Canada. Quat Res 5:273-296

Meade RH, Bobrovitskaya NN, Babkin VI (2000) Suspendedsediment and fresh-water discharges in the $\mathrm{Ob}$ and Yenisei rivers (1960-1988). Int J Earth Sci 89:578-591

Meyers PA (1997) Organic geochemical proxies of paleoceanographic, paleolimnologic and paleoclimatic processes. Org Geochem 27 $(5 / 6): 213-250$

Nesje A, Matthews JA, Dahl SO, Berrisford MS, Andersson C (2001) Holocene glacier fluctuations of Flatebreen and winter-precipitation changes in the Jostedalsbreen region, western Norway, based on glaciolacustrine sediment records. The Holocene 11:267-280

Nichols PD, Jones GJ, de Leeuw JW, Johns RB (1984) The fatty acid and sterol composition of two marine dinoflagellates. Phytochemistry 23(5):1043-1047

Parrish CC, Abrajano TA, Budge SM, Helleur RJ, Hudson ED, Pulchan K, Ramos C (2000) Lipid and phenolic biomarkers in marine ecosystems: analysis and applications. In: Wangersky PJ (ed) Marine chemistry. The Handbook of Environmental Chemistry, vol 5D. Springer, Berlin Heidelberg New York, pp 193-223

Peterson BJ, Holmes RM, McClelland JW, Vorosmarty CJ, Lammers RB, Shiklomanov AI, Shiklomanov IA, Rahmstorf S (2002) Increasing river discharge to the Arctic Ocean. Science 298:2171-2173

Polyakova YeI, Stein R (2004) Holocene paleoenvironmental implications of diatom and organic carbon records from the Southeastern Kara Sea (Siberian Margin). Quat Res 62:256-266

Prahl FG, Carpenter R (1984) Hydrocarbons in Washington coastal sediments. Estuarine Coastal Shelf Sci 18:703-720

Prahl FG, Muehlhausen LA (1989) Lipid biomarkers as geochemical tools for paleoceanographic study. In: Berger W, Smetacek V, Wefer G (eds) Productivity of the ocean: past and present. Life Sci Res Rep 44:271-290 (Wiley, New York)

Prahl FG, Ertel JR, Goni MA, Sparrow MA, Eversmeyer B (1994) Terrestrial organic-carbon contributions to sediments on the Washington margin. Geochim Cosmochim Acta 58(14):30353048

Rachold V, Eicken H, Gordeev VV, Grigoriev MN, Hubberten H-W, Lisitzin AP, Shevchenko VP, Schirmeister L (2004) Modern terrigenous organic carbon input to the Arctic Ocean. In: Stein R, Macdonald RW (eds) The Arctic Ocean organic carbon cycle: present and past. Springer, Berlin Heidelberg New York, pp 3356

Simstich J, Stanovoy V, Bauch D, Erlenkeuser H, Spielhagen RF (2004) Holocene variability of bottom water hydrography on the Kara Sea shelf (Siberia) depicted in multiple single-valve analyses of stable isotopes in ostracods. Mar Geol 206:147-164 
Stein R, Fahl K (2004) The Kara Sea: distribution, sources, variability and burial of organic carbon. In: Stein R, Macdonald RW (eds) The Arctic Ocean organic carbon cycle: present and past. Springer, Berlin Heidelberg New York, pp 237-266

Stein R, Stepanets OV (eds) (2000) Scientific cruise report of the Joint Russian-German Kara-Sea Expedition of RV "Akademik Boris Petrov" in 1999. AWI, Bremerhaven, Rep Polar Res 360

Stein R, Stepanets OV (eds) (2001) The German-Russian Project on Siberian River Run-off (SIRRO): scientific cruise report of the Kara Sea Expedition "SIRRO 2000" of RV "Akademik Boris Petrov" and first results. AWI, Bremerhaven, Rep Polar Mar Res 393

Stein R, Fahl K, Dittmers K, Niessen F, Stepanets OV (2003a) Holocene siliciclastic and organic carbon fluxes in the $\mathrm{Ob}$ and Yenisei estuaries and the adjacent inner Kara Sea: quantification, variability, and paleoenvironmental implications. In: Stein R, Fahl K, Fütterer DK, Galimov EM, Stepanets OV (eds) Siberian river run-off in the Kara Sea: characterisation, quantification, variability, and environmental significance. Proceedings in Marine Sciences, vol 6. Elsevier, Amsterdam, pp 401-434

Stein R, Fahl K, Fütterer DK, Galimov EM, Stepanets OV (eds) (2003b) Siberian river run-off in the Kara Sea: characterisation, quantification, variability, and environmental significance. Proceedings in Marine Sciences, vol 6. Elsevier, Amsterdam

Stein R, Dittfsmers K, Fahl K, Kraus M, Matthiessen J, Niessen F, Pirrung M, Polyakova Ye, Schoster F, Steinke T, Fütterer DK
(2004) Arctic (palaeo) river discharge and environmental change: evidence from Holocene Kara Sea sedimentary records. Quat Sci Rev 23:1485-1511

Stuiver M, Reimer PJ, Bard E, Beck JW, Burr GS, Hughen KA, Kromer B, McCormic G, van der Plicht J, Spurk M (1998) INTCAL 98 radiocarbon age calibration, 24000-0 cal BP. Radiocarbon 40:1041-1083

Thompson R, Oldfield F (1986) Environmental magnetism. Allen and Unwin, Boston

Velichko AA, Dolukhanov PM, Rutter NW, Catto NR (eds) (1997) Quaternary of northern Eurasia: late Pleistocene and Holocene landscapes, stratigraphy and environments. Quat Int $41 / 42$

Volkman JK (1986) A review of sterol markers for marine and terrigenous organic matter. Org Geochem 9(2):83-99

Volkman JK, Barrett SM, Dunstan GA, Jeffrey SW (1993) Geochemical significance of the occurrence of dinosterol and other 4methyl sterols in a marine diatom. Org Geochem 20:7-15

Vorobyeva GA (1994) Paleoclimates around Lake Baikal in Pleistocene and the Holocene. Baikal as a Nature Laboratory for Global Change, vol 2. Lisna, Irkutsk, pp 54-55

Yunker MB, Macdonald RW, Veltkamp DJ, Cretney WJ (1995) Terrestrial and marine biomarkers in a seasonally ice-covered Arctic estuary-integration of multivariate and biomarker approaches. Mar Chem 49:1-50 